\title{
Micropropagation of guava (Psidium guajava L.)
}

\author{
${ }^{* 1}$ Sabah A. Hassanen, ${ }^{1}$ Mohamed I. Daib and ${ }^{2}$ Sayed A. Omar \\ ${ }^{1}$ Tissue Culture Unit, \\ ${ }^{2}$ Breeding Unit, Genetic Resources Department, Ecology and Dry Land Agriculture Division, Desert Research \\ Center, El-Matareya, Cairo Egypt. \\ Corresponding Author: Sabah A. Hassanen
}

\begin{abstract}
Guava (Psidium guajava L.) plant is widely adopted and can tolerate frost, drought and salinity conditions. In the present study, a rapid, simple and efficient protocol for in vitro propagation of guava ( $P$. guajava L.) from nodal segments of adult trees grown in the field was established. Explants collected in Autumn and cultured on Murashige and Skoog (MS) medium supplemented with 6-benzyl adenine (BA) at $8.9 \mu \mathrm{M}$, plus indole-3-butyric acid (IBA) at $0.98 \mu \mathrm{M}$ showed the best response in the in vitro establishment (91.7\% sprouting percentage and shoot length of $1.75 \mathrm{~cm})$. In addition, $100 \mathrm{mg} / \mathrm{l}$ ascorbic acid and $150 \mathrm{mg} / \mathrm{l}$ citric acid as antioxidants and Polyvinylpyrrolidone (PVP) at $100 \mathrm{mg} / \mathrm{l}$ and activated charcoal (AC) at $2 \mathrm{~g} / \mathrm{l}$ as absorbents were added to the establishment medium to reduce phenolic compounds. Regarding average number and length of shoots per explant, BA was more effective than kinetin (kin). Maximum rooting percentage (66.7\%) occurred on solid half-strength MS medium containing indol-3-butyric acid (IBA) at $9.8 \mu \mathrm{M}$. Fifty percent (50\%) rooted plantlets were successfully acclimatized in the greenhouse in soil mixture of sand, grand soil and peat moss at equal volumes, and subsequently established outside the greenhouse.
\end{abstract}

Keywords: Psidium guajava L., micropropagation, nodal segment, seasonal variation, phenolic compounds

Date of Submission: $\mathrm{xx}-\mathrm{xx}-\mathrm{xxxx}$

Date of acceptance: $\mathrm{xx}-\mathrm{xx}-\mathrm{xxxx}$

Abbreviations: AC, Activated charcoal; BA, 6-benzyl adenine; IBA, indole-3-butyric acid; KIN, Kinetine (6furfurylaminopurine); MS, Murashige and Skoog; NAA, $\beta$-naphthalene acetic acid; PGRs, plant growth regulators; PVP, Polyvinylpyrrolidone.

\section{Introduction}

Guava (Psidium guajava L.) is one of the economical fruit crops in the Myrtaceae family, generally known as 'the apple of tropics'. It considers one of the most important fruits of high nutraceutical value in international trade and domestic economy of several tropical and subtropical countries (Chandra et al., 2010 and Kamle et al., 2013). Guava plant is widely adopted and can tolerate frost, drought and salinity conditions (Samson, 1986). It is an important food crop and medicinal plant in tropical and subtropical countries and is widely used as food and in folk medicine around of the world (Rosa et al., 2008). The fruit of guava is highly valued and used in a number of different ways. It is contains four times higher vitamin $\mathrm{C}$ than any other fruits. Furthermore, the high concentrations of pectin content in guava fruit plays a noteworthy role in cholesterol drop and thus losses the cardiovascular diseases (Singh, 2005; Ria et al., 2010 and Bajpai et al., 2016). It is well accepted by the consumers, and makes a beneficial contribution to the human diet due to its rich source of minerals and functional components such as vitamins and phenolic compounds (Luiz et al., 2011). Different parts of the plant have been used extensively in traditional folk medicine. Traditionally, guava is used for the treatment of various ailments like diarrhea wounds, rheumatism, lung problems, ulcers etc. (Sanda et al., 2001).

It is low in calories and fats but carries several antioxidant polyphenolic and flavonoid compounds that play a crucial role in the prevention of many important diseases like prostate, colon, and epidermal cancers, as well as leukemia (Manosroi et al., 2005; Chen et al., 2007; Gutiérrez et al., 2008; Chen et al., 2010; and Ryu et al., 2012), aging, infections, etc. The wood is moderately strong and durable indoors; it is used for handles and in carpentry and turnery, and also for building timbers, wood ware and carvings. The flowers provide nectar for bees and contribute to honey production (Verheij and Coronel, 1991). Guava is generally cross-pollinated and is usually be propagated by seeds, which leads to a wide range of genetic variability (Mehmood et al., 2013, 2014). As a result, there are differences in fruit quality and the quantity of yield. However, there is no way other than the seeds for propagation. Thus to meet the demand of planting material, it is necessary to obtain a true to type plants through a method of rapid vegetative propagation. Nevertheless, vegetative (asexual) propagation by cutting is practiced on a limited scale and is not successful because it is hard to root. Plant tissue culture (micropropagation) is recognized as one of the key areas of biotechnology because of its potential use to regenerate elites while conserving valuable plant genetic resources (Liu and Yang, 2011). In addition, in vitro

DOI: $10.9790 / 2380-1007022835 \quad$ www.iosrjournals.org $\quad 28 \mid$ Page


propagation approaches have been used as an efficient tool for the large-scale propagation of a number of commercially important plants, and it has proved that tissue culture has several potential advantages over conventional propagation methods, like high multiplication rate in short time, season-independent production of plants, production of disease-free plant and germplasm conservation (George and Debergh, 2008). In commercial industry, the maintenance of true-to-type nature of the in vitro propagated plants is an important requisite for upholding certain agronomic and horticultural traits when using elite genotype. From previous studies, some authors worked on micropropagation of guava cv. Plant Prabhat (Mishra et al., 2007), cv. Allahabad and cvs. Jen-Ju, Li-Tzy, Paistani, Shyh-Jii, and Huang.(Saelew and yang, 2009). In vitro propagation of guava may be an efficient way to produce superior seed strains of guava (local name Ghonamy).

In Egypt, there are some superior guava seed strains, which are characterized by shape, color, taste, flavor and low content of seeds. (Figure 1). Thus, one of these strains was selected as a superior plant source for in vitro propagation in the present study. However, there are several problems associated with in vitro culture of explants obtained from mature trees of guava such as browning or blackening of medium and/or explants due to leaching of phenolic, microbial contamination, and in vitro tissue recalcitrance etc. High phenolic exudation during the excision of plants, explant browning, medium discoloration, and slow growth response have made the ordeal for workers dealing with several woody tree species including guava (Rout et al., 2000). Therefore, the present study aimed to develop an efficient in vitro propagation protocol for rapid and mass propagation of these seed strains grown in Egypt (local name Ghonamy). As well as for solving some problems which facing micropropagation of guava.

\section{Explant source and sterilization}

\section{Materials And Methods}

Nodal segments of healthy lateral branches of guava (Psidium guajava L.) were collected in Spring, Summer, and Autumn from mature field-grown superior trees in El-Kalyoubia governorate, Egypt. Nodal segments were chosen for the in vitro propagation of $P$. guajava L. because shoot tips were too small and very difficult to be sterilized or survived. The explants were placed under running tap water for one hour followed by washing with commercial detergent (Pril) for five minutes, then washed with tap water for one hour. Followed by keeping in Benlate (antifungal) $(1 \mathrm{~g} / \mathrm{l})$ along with few drops of Tween-20 for ten minutes. Later on, explants were washed thoroughly by keeping under running tap water till all residues get washed out. Surface sterilization was done by immersing explants in $70 \%$ ethanol (v/v) for one minute followed by $0.05 \% \mathrm{HgCl} 2$ (mercuric chloride) solution containing few drops of Tween-20, for two minutes followed by 3-4 washing using double distilled water. Then the explants were disinfected, using $2 \%(\mathrm{w} / \mathrm{v})$ sodium hypochlorite $(\mathrm{NaOCl})$ for 10 minutes followed by 5-6 washing with sterilized distilled water. Finally, explants were left under aseptic conditions in laminar air flow cabinet in an antioxidant solution $(150 \mathrm{mg} / \mathrm{l}$ citric acid and $100 \mathrm{mg} / \mathrm{l}$ ascorbic acid) until culture to overcome phenol exudation.

\section{Culture media and conditions}

Explants were cultured on Murashige and Skoog (MS) basal medium (Murashige and Skoog, 1962; Duchefa, Haarlem, Netherlands) with $30 \mathrm{~g} / \mathrm{l}$ sucrose, $100 \mathrm{mg} / \mathrm{l}$ myo-inositol and solidified with $3 \mathrm{~g} / \mathrm{l}(\mathrm{w} / \mathrm{v})$ phytagel (Duchefa, Haarlem, Netherlands). Antioxidant agents viz. $150 \mathrm{mg} / \mathrm{l}$ citric acid and $100 \mathrm{mg} / \mathrm{l}$ ascorbic acid and absorbent as $100 \mathrm{mg} / \mathrm{l}$ polyvinylpyrrolidone (PVP) and $2 \mathrm{~g} / \mathrm{l}$ activated charcoal (AC), were added to establishment medium for reduce phenolic compounds. Various concentrations and combinations of plant growth regulators (PGRs, Sigma Cell Culture, min. 90\%, St. Louis, USA) were added to the culture medium according to the growth stage. The $\mathrm{pH}$ of the media was adjusted to $5.7 \pm 0.1$ then, dispensed in culture tubes $25 \times 150 \mathrm{~mm}$ containing $15 \mathrm{ml}$ of MS medium (for initiation and rooting stages) or large jars (350 ml) contained $40 \mathrm{ml}$ (for multiplication stage) and autoclaved at $121^{\circ} \mathrm{C}$ at a pressure of $1.1 \mathrm{~kg} / \mathrm{cm}^{2}$ for $15 \mathrm{~min}$ (Harvey Sterilemax autoclave, Thermo Scientific, USA). Cultures were incubated in a temperature of $25 \pm 2^{\circ} \mathrm{C}$ under dark (for initiation and rooting stages) for one week after that, exposed to photoperiod of 16 hours with a light intensity of $20 \mu \mathrm{Mol} / \mathrm{m} 2 / \mathrm{s}$ (F140t9d/38, Toshiba), and under relative humidity of 60-65\%.

\section{Effect of seasonal variation}

Nodal segments were collected in three different seasons (Spring, Summer, and Autumn) in the middle of every month and cultured on MS medium without PGRs, in order to determine the most suitable season to take the explants. After four weeks of culturing, survival and browning percentage (\%) were recorded.

\section{Culture establishment}

Explants of guava cultured on MS medium supplemented with 6-benzyl adenine (BA), at different concentrations of $(2.22,4.40$ and $8.90 \mu \mathrm{M})$ and indole-3-butyric acid (IBA) $0.98 \mu \mathrm{M}$ in addition MS medium without PGRs was used as a control. After four weeks, sprouting percentage $(\%)$ and average shoot length $(\mathrm{cm})$ were recorded. 


\section{Shoot multiplication}

In this experiment, the in vitro established shoots were cultured on MS medium supplemented with different concentrations of BA $(2.22,4.40,8.90$, and $17.80 \mu \mathrm{M})$ and kinetine (kin) $(2.32,4.60,9.3$, and 18.6 $\mu \mathrm{M})$ and in addition MS medium free from cytokinins was served as control. After four weeks of culturing, were recorded proliferation rate (average number of new shoots produced per explant) and average shoot length (cm). The micropropagation cycle consisted of a monthly subculture.

\section{Rooting induction and acclimatization}

Elongated shoots derived from nodal explants, were cultured on solid half strength MS medium containing (IBA) (Sigma Cell Culture, St. Louis, USA) at $(0.0,2.46,4.9,7.36$, and $9.8 \mu \mathrm{M})$ and $\beta$-naphthalene acetic acid (NAA) at concentrations of $0.0,2.69,5.37,8.06$ and $10.74 \mu \mathrm{M}$.. After four weeks from culturing were evaluated the percentage of rooted shoots (\%), an average number of roots/ shoot and an average length of a root $(\mathrm{cm})$. The rooted shoots were removed from the medium, washed in running tap water to remove all traces of phytagel and dipped carefully for $5 \mathrm{~min}$ in $1 \%$ Benlate (systemic fungicide) and transferred to $6 \mathrm{~cm}$ diameter plastic pots filled with a mixture of sand, garden soil and peat moss at equal volume. Initially, plantlets were covered with a polyethylene bags and transferred to the greenhouse at $\left(26 \pm 2 \mathrm{C}^{\circ} 70-80 \%\right.$ relative humidity). After eight weeks, polyethylene bags were eliminated gradually from pots for compatible hardening. The plantlets were irrigated with 1/10 MS medium every five days. Finally, they were transferred outside the greenhouse under natural light conditions.

\section{Statistical analysis}

Experimental data were conducted as completely randomized design, with 45 replicates for each treatment. Variance analysis of data was carried out using ANOVA program for statistical analysis. The differences among means for all treatments were tested for significance at 5\% level by using Duncan,s multiple range test Duncan (1955) and modified by Snedecor and Cochran (1990).

\section{Effect of seasonal variation}

\section{Results And Discussion}

The efficiency of micropropagation through nodal segments culture in mature trees depends greatly on the season of explants. Data in Table 1 show that the browning percentage had the lowest value during Autumn $(6.70 \%)$ and the highest survival percentage (93.3\%) was observed during Autumn. Higher explants establishment and lower loss of the culture explants from browning were obtained. On the other hand, the lowest survival percentage $(13.3 \%)$ and the highest browning percentage of explants $(86.7 \%)$ were obtained in Summer. Comparison in a different season to take nodal segments for culturing it was found that the highest survival percentage and low browning was more effective in Autumn and Spring than Summer, in Summer season had lower survival percentage and higher browning percentage.

There is the enormous problem for an establishment of in vitro cultures of woody plants. Roussos and Pontikis (2001) reported that explant collection was a major factor influencing the relative concentrations of various phenolic compounds in olive explant.

Table (1): Effect of seasonal variation on survival and browning percentage of guava P. guajava L.

\begin{tabular}{|l|c|c|}
\hline \multicolumn{1}{|c|}{ Seasons } & Survival \% & Browning \% \\
\hline Spring & $73.3 \mathrm{~b}$ & $26.70 \mathrm{~b}$ \\
\hline Summer & $13.3 \mathrm{c}$ & $86.70 \mathrm{a}$ \\
\hline Autumn & $93.3 \mathrm{a}$ & $6.70 \mathrm{c}$ \\
\hline
\end{tabular}

Means followed by the same latter within a column are not significantly different at $P<0.05$

Also, Saelew and Yang (2009) who found that survival percentage and fresh weight were higher in the treatment of using Autumn and Spring shoots than Summer shoots. Phenolic exudation during the excision of plants of several woody tree species including guava cause browning of media occurred (Rout et al., 2000). Browning of tissue is caused by the oxidation of tannin and polyphenols and the formation of quinones which are highly reactive and toxic to the plant tissues contain these substances in separate pools or compartments. During tissue wounding, these pools are integrated and the oxidation process is initiated (Monaco et al., 1977). Addition of antioxidants (ascorbic and citric acid), activated charcoal (AC) and (PVP) as adsorbent agent to establishment medium has been reported as effective in preventing an oxidation of phenol (kumar and kumar, 1998, Ahmed et al., 2013 and Ahmed et al., 2016). Therefore, oxidized phenolic compounds may inhibit enzyme activity and result in darkening of the culture medium and subsequent lethal for explant. As browning of media 
prevents further progress in biotechnology of, woody trees. From the previously results, it was clear that high levels of growth promoting substances and low growth inhibitors during Autumn may be responsible for the high survival percentage of explants in vitro establishment.

\section{Culture establishment}

The plant regeneration from nodal segments is considered to be one of the most promising ways for multiplying a selected variety true to type (Ahmed and Anis, 2014). Concerning the establishment nodal segments of $P$. guajava L. data in Table 2 showed that sprouting percentage ranged between 16.7 to $91.7 \%$. Data obtained after four weeks of culture revealed that nodal segments gave the highest sprouting percentage (91.7\%) and average shoot length $(1.75 \mathrm{~cm})$ on MS medium supplemented with $8.9 \mu \mathrm{M} \mathrm{BA}$ and $0.98 \mu \mathrm{M} \mathrm{IBA}$, (Figure $2 \mathrm{~A}$ ), followed by MS medium containing $4.4 \mu \mathrm{M} \mathrm{BA}$ and $0.98 \mu \mathrm{M}$ IBA which gave $75 \%$ sprouting percentage and average shoot length of $1.77 \mathrm{~cm}$.

Table (2): Effect of different concentrations of PGRs (BA and IBA) on sprouting percentage and shoot length $(\mathrm{cm})$ for nodal segments of guava $P$. guajava

\begin{tabular}{|lc|c|c|}
\hline \multicolumn{2}{|c|}{$\begin{array}{c}\text { PGRs }(\boldsymbol{\mu M}) \\
\text { concentrations }\end{array}$} & Sprouting \% & Shoot length (cm) \\
\hline BA & IBA & & \\
\hline 0.0 & 0.0 & $16.7 \mathrm{~g}$ & $1.77 \mathrm{~b}$ \\
\hline 2.22 & 0.0 & $33.3 \mathrm{f}$ & $1.40 \mathrm{c}$ \\
\hline 4.40 & 0.0 & $58.3 \mathrm{~d}$ & $1.10 \mathrm{~d}$ \\
\hline 8.90 & 0.0 & $53.7 \mathrm{e}$ & $0.90 \mathrm{e}$ \\
\hline 2.22 & 0.98 & $60.7 \mathrm{c}$ & $1.83 \mathrm{a}$ \\
\hline 4.40 & 0.98 & $75.0 \mathrm{~b}$ & $1.77 \quad \mathrm{~b}$ \\
\hline 8.90 & 0.98 & $91.7 \mathrm{a}$ & $1.75 \quad \mathrm{~b}$ \\
\hline
\end{tabular}

Means followed by the same latter within a column are not significantly different at $P<0.05$

It noticed that, MS medium containing $2.22 \mu \mathrm{M}$ BA and $0.98 \mu \mathrm{M}$ IBA gave the highest average shoot length was $1.83 \mathrm{~cm}$. The sprouting of shoots percentage increased gradually with an increase in BA concentration. On the other hand, the lowest sprouting percentage was recorded on MS medium without plant growth regulators (control). From the previous results, it is clear that MS medium containing $8.9 \mu \mathrm{M} \mathrm{BA}$ and $0.98 \mu \mathrm{M}$ IBA gave rise to the best results for nodal segments. These results are supported by (Mishra et al., 2007, Saelew and Yang 2009, and Usman et al., 2012) who found that the best initial nodal segment of guava on medium containing IBA supplemented with $2 \mathrm{mg} / \mathrm{l} \mathrm{BA}$. This clearly indicated that BA in combination with low concentration of auxin to be fruitful for axillary and apical bud sprouting in certain specie (Joshi and Dhar, 2003 and Dhar and Joshi, 2005).

\section{Shoot multiplication}

Data on multiple shoot induction from nodal segments explant culture on MS medium with different concentrations of cytokinins (BA and Kin) present in Table 3. Multiplication was seen with all tested cytokinins (BA and Kin) since, Table 3 showed that the highest average number of shoots per explant was 4.8 and the highest average shoot length reached $4.3 \mathrm{~cm}$ on MS medium containing $4.4 \mu \mathrm{M}$ BA compared to the other BA treatments (Figure 2 B). Concerning Kin they gave lower results in comparison with BA. When cultured on medium supplemented with Kin $(18.6 \mu \mathrm{M})$ gave 3.1 shoots/explant and shoot length of $1.9 \mathrm{~cm}$. There was no sign of growth when explants were cultured on the medium without PGRs. This indicated that cytokinins had a positive and stimulating effect because their uptake, transport, and metabolism differ between varieties and they can interact with endogenous cytokinins of explants (Vanstaden et al., 2008). 
Table (3): Effect of cytokinins (BA and Kin) on in vitro shoot multiplication of P.guajava $\mathrm{L}$ after four weeks from culture.

\begin{tabular}{|c|c|c|c|}
\hline & $\begin{array}{l}\text { PGRs }(\mu \mathrm{M}) \\
\text { concentrations }\end{array}$ & $\begin{array}{l}\text { Average number of } \\
\text { shoots per explants }\end{array}$ & $\begin{array}{l}\text { Average shoot } \\
\text { length }\end{array}$ \\
\hline$\overline{B A}$ & Kin & & \\
\hline 0.0 & 0.0 & $0.0 \mathrm{~g}$ & $0.0 \mathrm{f}$ \\
\hline 2.22 & 0.0 & $1.8 \mathrm{f}$ & $2.3 \mathrm{c}$ \\
\hline 4.40 & 0.0 & $4.8 \mathrm{a}$ & $4.3 \mathrm{a}$ \\
\hline 8.90 & 0.0 & $3.5 \mathrm{~b}$ & $3.7 \mathrm{~b}$ \\
\hline 17.80 & 0.0 & $2.1 \mathrm{e}$ & $1.8 \mathrm{~d}$ \\
\hline 0.00 & 2.32 & $1.7 \mathrm{f}$ & $1.4 \mathrm{e}$ \\
\hline 0.00 & 4.6 & $2.1 \mathrm{e}$ & $1.7 \mathrm{~d}$ \\
\hline 0.00 & 9.3 & $2.5 \mathrm{~d}$ & $2.3 \mathrm{c}$ \\
\hline 0.00 & 18.6 & $3.1 \mathrm{c}$ & $1.9 \mathrm{~d}$ \\
\hline
\end{tabular}

Means followed by the same latter within a column are not significantly different at $P<0.05$

Increasing BA concentration up to $8.9 \mu \mathrm{M}$ in medium decreased average number of shoots and shoot length. From the observations, BA more suitable than kinetine for shoot multiplication, this finding is in agreement with many authors who reported that BA has superior shoot induction ability over other cytokinins (Siddique and Anis, 2009 and Silveiraa et al., 2016). BA is not easily broken down and therefore persists in the medium. It is also possible that the amount of BA that got conjugated in the medium was smaller than what happened to the other plant hormones. This would then have larger amount of BA existing in their free or ionized forms and were readily made available to plant tissues from the medium (Buah, et al., 2010). Generally, BA was more effective on shoot formation than Kin in guava, indicating cytokinin specificity for shoot induction in its tissue. It is well known that cytokinins stimulate plant cell division and participate in the release of lateral bud dormancy, in the induction of adventitious bud formation, in the growth of lateral buds and in the cell cycle control (Gaspar et al. 2003). This might be due to its concentration fit to stimulate the tissue to metabolize the endogenous hormones and induce the production of endogenous for hormones the induction of multiple shoots.

\section{Rooting induction and acclimatization}

For better establishment of plantlets in the field, well developed rooting system is necessary. The multiplied shoots were induced to regenerate roots in half MS sold medium supplement with different concentration of IBA and NAA. Maximum rooting percentage $(66.7 \%)$ occurred in vitro in sold half MS medium with $9.8 \mu \mathrm{M}$ IBA (Table 4 and Figure $2 \mathrm{C}$ - D), the number of roots per shoot was (3.60) and root length reached $(3.33 \mathrm{~cm})$. Also, the second best rooting percentage $(49.5 \%)$ with average root number per shoot (2.92), and length $1.9 \mathrm{~cm}$, were obtained on MS medium supplemented with $7.36 \mu \mathrm{M}$ IBA.

Table (4): Effect of half strength MS medium supplemented with auxins (IBA and NAA) on the in vitro rooting

\begin{tabular}{|c|c|c|c|c|}
\hline $\begin{array}{l}\text { Conce } \\
\text { IBA }\end{array}$ & NAA & $\begin{array}{c}\text { Percent of rooted } \\
\text { shoots } \\
\%\end{array}$ & $\begin{array}{c}\text { No. of roots per } \\
\text { shoot }\end{array}$ & $\begin{array}{c}\text { Average length of } \\
\text { root } \\
(\mathbf{c m})\end{array}$ \\
\hline 0.0 & 0.0 & $0.00 \mathrm{~h}$ & $0.00 \mathrm{f}$ & $0.00 \mathrm{e}$ \\
\hline 2.46 & 0.0 & $41.7 \mathrm{~d}$ & $2.00 \mathrm{~d}$ & $2.03 \mathrm{c}$ \\
\hline 4.90 & 0.0 & $45.8 \mathrm{c}$ & $2.50 \mathrm{c}$ & $2.41 \mathrm{~b}$ \\
\hline 7.36 & 0.0 & $49.5 \mathrm{~b}$ & $2.92 \mathrm{~b}$ & $1.90 \mathrm{~d}$ \\
\hline 9.80 & 0.0 & $66.7 \mathrm{a}$ & $3.60 \mathrm{a}$ & $3.33 \mathrm{a}$ \\
\hline 0.0 & 2.69 & $20.22 \mathrm{~g}$ & $1.30 \mathrm{e}$ & $1.94 \mathrm{~d}$ \\
\hline 0.0 & 5.37 & $27.8 \mathrm{f}$ & $1.50 \mathrm{e}$ & $2.22 \mathrm{c}$ \\
\hline 0.0 & 8.06 & $32.33 \mathrm{e}$ & $1.70 \mathrm{e}$ & $2.40 \mathrm{~b}$ \\
\hline 0.0 & 10.74 & $40.33 \mathrm{~d}$ & $1.90 \mathrm{~d}$ & $2.00 \mathrm{~d}$ \\
\hline
\end{tabular}

Means followed by the same latter within a column are not significantly different at $P<0.05$ 
On the other hand, half strength MS medium without auxin (control) failed to induce rooting. In the present study, half strength MS medium was adequate for root induction. Relatively, low salt concentration in medium are known to enhance rooting and shoot in several plants species (Zhou, et al., 2010). Moreover, all concentrations and type of auxin used, markedly, influenced the percentage of root formation. IBA is commonly used to promote root initiation both in vitro and in the propagation by cutting (Pan and Zhao, 1994 and Housman 2003) has shown that in tissue culture media, IBA oxidized slowly (10\%), Its slow movement and delayed degradation may be the primary reason for better performance of IBA as compared to NAA. The effectiveness of IBA to induction roots was reported by (Sambe et al., 2010). IBA is an auxin with high potential for root induction on shoot.

The superiority of IBA for root induction over other auxin has also been reported in many plants on Garcinia indica (Malik et al., 2005), Trigonella foenum-graecum L. (Asim et al., 2010), pistachia vera L. (Gabr and Hassanen, 2012) Cicer arietinum L., (Tripathi et al., 2013) and Cajanus cajan L. (Raghavendra and Sudhakar, 2014). As shown by Zhou et al., (2010) who found that $100 \%$ rooting percentage of peach rootstock by used IBA. It is clear that, IBA was significantly more efficient than NAA for root formation. Fifty percent $(50 \%)$ of rooted plants were successfully acclimatized in the greenhouse (Figure $2 \mathrm{E}$ ) having light intensity (white fluorescent tubes; irradiance of 100-125 $\mu \mathrm{Mol} \mathrm{m}-2 \mathrm{~s}-1$ ), 70-80\% humidity with temperature ranging from 26-28 $C^{\circ}$ (Sutter et al., 1992). The plantlets were successfully transferred outside the greenhouse (Figure2 F-G). In conclusion, a reproducible and efficient micropropagation protocol has been developed, using nodal segment explants collected in Autumn from elite plant guava ( . guajava L.). Moreover, there are difficulties in establishing aseptic cultures from mature explants along with browning of explants have limited progress towards the development of in vitro propagation. Multiplication rate with uniform growth and length of shoots has been achieved. The shoot rooted in vitro and $50 \%$ of plantlets successfully acclimatized in a greenhouse. From previous data, $P$. guajava L. needs more studies to improvement the rooting percentage and acclimatization.

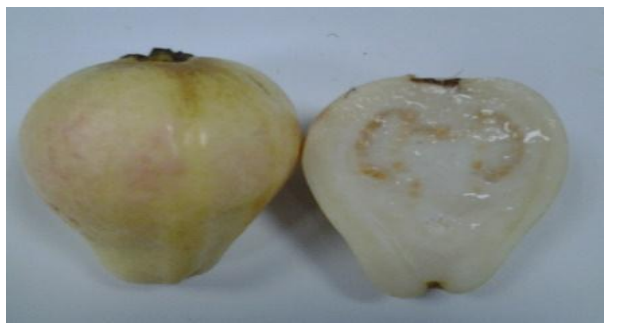

Figure 1 Fruits of guava $P$. guajava L seed strain.
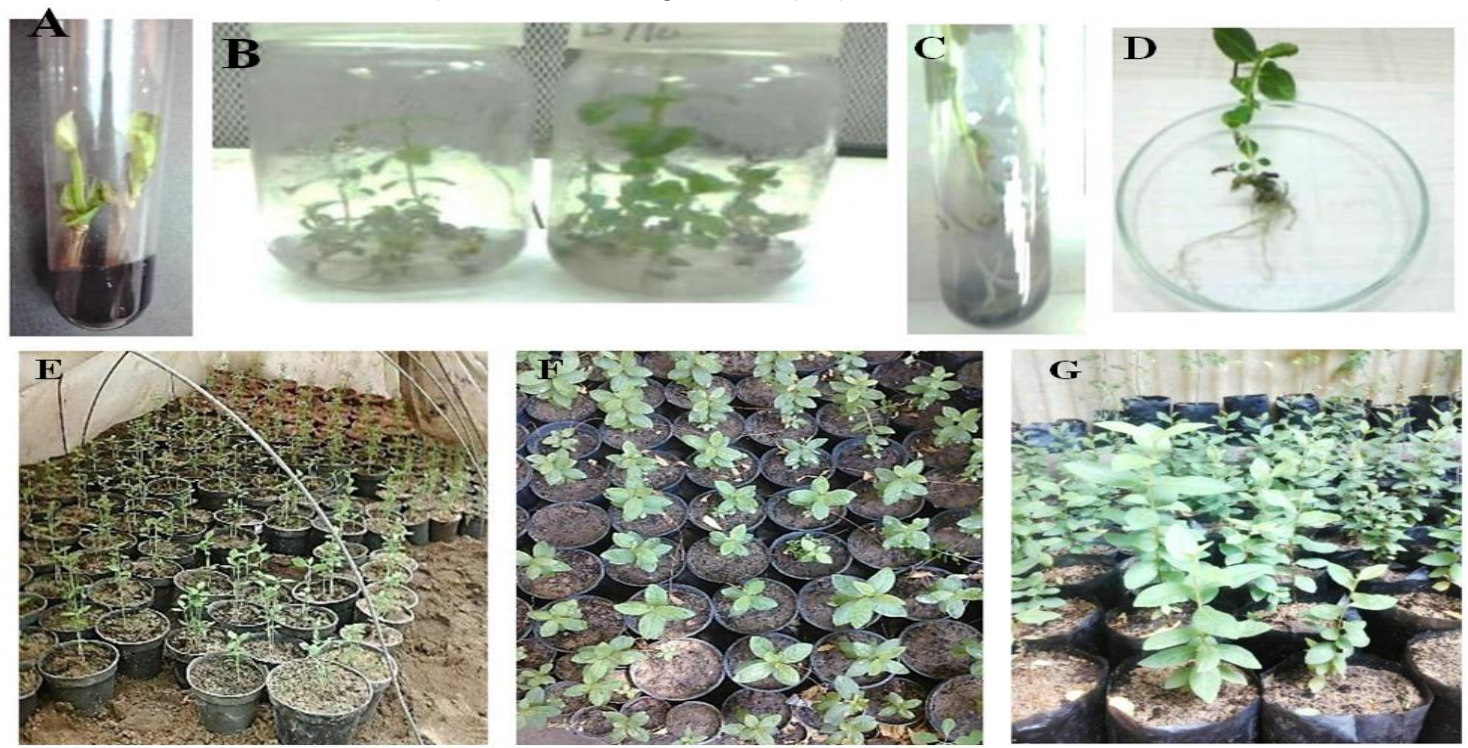

Figure 2:

A. Intitation of Psidium guajava L nodal segments on MS medium supplemented with $8.9 \mu \mathrm{m}$ BA and $0.98 \mu \mathrm{M}$ IBA.

B. Multiplication shoots of Psidium guajava L on MS medium supplemented with $4.4 \mu \mathrm{M}$ BA. C-D. Rooting shoots of Psidium guajava L on MS medium supplemented with sold half MS medium with $9.8 \mu \mathrm{M}$ IBA.

Acclimatization of Psidium guajava $\mathbf{L}$.

E. Two-months old rooted plantlets acclimatized in the greenhouse.

F. Six-months old rooted plantlets grown outside the greenhouse.

G. Eight- months old rooted plantlets grown outside the greenhouse. 


\section{References}

[1] Ahmad, I. and R. Anis (2014). Rapid in vitro propagation system through shoot tip cultures of Vitex trifolia (L.) an important multipurpose plant of the Pacific traditional Medicine. Physiol Mol Biol. Plants 20(3):385-392.

[2] Ahmad, I.; M.jaskani; J. Nafeesl; M. Ashraf and R. Qureshi (2016). Control of media browning in micropropagation of guava (psidium guajava L.). Pak. J.

[3] Ahmad, I.; T. Hussain; I. Ashraf; M. Nafees; Maryam; M. Rafay and M. Iqbal (2013). Lethal effects of secondary metabolites on plant tissue culture. American-Eurasian Journal of Agricultural \& Environmental Sciences, vol. 13 (4) 539-547.

[4] Asim, M.; N. Hussain; EM. Umer; M. Zubair; SB. Hussain; S. Saeed; TS. Rafique and C. Sancak (2010). In vitro shoot regeneration of fenugreek(Trigonella foenum-graecum L.) using different cytokinins. Afr. J. Biotechnol.,9(42):7174-7179.

[5] Bajpai, A.; S. Kalim; R. Chandra and M. Kamle (2016). Recurrent Somatic Embryogenesis and Plantlet Regeneration in Psidium guajava L. Braz. Arch. Biol. Technol., vol.59: e16150170.

[6] Buah, J. N.; E. Danso and K. J. Taah (2010). The effects of different concentrations cytokinins on the in vitro multiplication of plantain (Musa sp.)," Biotechnology, vol. 9 No. 3, 343-347.

[7] Chandra, R.; M. Kamle; and A. Bajpai (2010). 'Guava' In: (Eds. H.P. Singh et al.,): Advances in Horticultural Biotechnology vol.1-Regeneration Systems - Perennial fruit crops plants and spices. Westville publishers, New Delhi., 103-120.

[8] Chen K.C.; C.L. Hsieh and C.C. Peng (2007). Brain derived metastatic prostate cancer DU-145 cells are effectively inhibited in vitro by guava (Psidium guajava L.) leaf extracts. Nutr. Cancer. 58(1):93-106.

[9] Chen, K.C.; C.M. Chuang and L.Y. Lin (2010). The polyphenolics in the aqueous extract of Psidium guajava kinetically reveal an inhibition model on LDL glycation. Pharm. Biol. 48 (1):23-31.

[10] Dhar, U. and M. Joshi (2005). Efficient plant regeneration protocol through callus for Saussurea obvallata (DC) Edgew. (Asteraceae): effect of explant type, age and plant growth regulators. Plant Cell Rep., 24: 195-200.

[11] Duncan, D.B. (1955). Multiple range and multiple F test. Biometrics, 11, 1-42.

[12] Gabr, M. F. and S. A. Hassanen (2012). In vitro propagation of Pistacia vera L. rootstock. Cetrina.7 (1) 25-31.

[13] Gaspar, T.; C. Kevers; O. Faivre-Rampant; M. Crèvecoeur; C. Penel; H. Greppin; J. Dommes (2003). Changing concepts in plant hormone action. In Vitro Cell Dev. Biol. Plant.39:85-106.

[14] George, E.F. and P.C. Debergh (2008). Micropropagation: uses and methods. In: George E.F.; M.A. Hall and G. De klerk, eds. Plant propagation by tissue culture. $3^{\text {rd }}$ ed. Dordrecht: Springer, vol. 1, 19-64.

[15] Gutiérrez, R.M.; S. Mitchell and R.V. Solis (2008) Psidium guajava: a review of its traditional uses, phytochemistry and pharmacology. J Ethnopharmacol., 17(1):1-27.

[16] Housman, J.F., (2003). Change in peroxidase activity auxin level and ethylene production during root formation by poplar shoot raised in vitro. Plant Growth Regular., 13(3) 263-268.

[17] Jaiswal, V.S. and M.N. Amin (1992). Guava and Jack fruit. In: Biotechnology of Perennial fruit crops (Ed). F.A. Hammerselag and R.E. Litz. CAB international, Wallingford, U.K., 421-431.

[18] Joshi, M. and U. Dhar (2003). In vitro propagation of SaussureaS obvallata (DC) Edgew. - an endangered ethnoreligious medicinal herb of Himalaya. Plant Cell Rep., 21: 933- 939.

[19] Kamle, M.; P. Kumar; A. Bajpai; S. Kalim and R. Chandra (2013). Assessment of genetic fidelity of in vitro regenerated guava (Psidium guajava L.) plants using DNA based markers. New Zealand J. Crop. Hort. Sci. 42(1)1-9.

[20] Kumar, A. and V. Kumar (1998). Clonal culture of important fruit crops International Book Distributing Company, India 1-55.

[21] Liu, X. and G. Yang (2011). Clonal propagation of guava (Psidium guajava L.) on nodal explants of mature trees. Inter. J. Plant Bio., 2: 7-10.

[22] Luiz C. C.; A. F., Carlos and F. V. Santos. (2011). Antioxidant content in guava (Psidium guajava L.) and araca (Psidium spp.) germplasm from different Brazilian regions. Plant Genetic Resources: Characterization and Utilization, 9:384-391.

[23] Malik, S.K.; R. Chaudhur and R.K. Kalia (2005). Rapid in vitro multiplication and conservation of Garcinia indica: A tropical medicinal tree species. Sci. Hort., 106: 539-553.

[24] Manosroi, J.; P. Dhumtanom;and A. Manosroi (2005). Anti-proliferative activity of essential oil extracted from Thai medicinal plants on KB and P388 cell lines. Cancer Lett., 235(1):114-120.

[25] Mehmood, A.; M.J. Jaskani; S. Ahmad and R. Ahmad (2013). Evaluation of genetic diversity in open pollinated guava by IPBS primers.Pak.. J. Agri. Sci., 50: 591-597.

[26] Mehmood, A.; M.J. Jaskani; I.A. Khan; S. Ahmad; R. Ahmad; S. Luo and N.M. Ahmad (2014). Genetic diversity of Pakistani guava (Psidium guajava L.) germplasm and its implications for conservation and breeding. Sci. Hortic., 172: $221-232$.

[27] Mishra, M.; R. Chandra; R. Pati and A. Bajpai (2007). Micropropagation of fruit crops plants and spices. Westville publishers, New Delhi. 103-120.

[28] Monaco, L.C.; C.R. Lopes and M.L. Carelli (1977). Isomeros deacido horagenicoem species de coffea. Cinecia Cultura Recife, 26: 240 .

[29] Murashige, T. and F. Skoog (1962). A revised medium for rapid growth and bioassays with tobacco tissue culture. Physiol Plant., 15: 473-497.

[30] Pan, R. and Z. Zhao (1994). Synergistic effect of plant growth retarutting of dants and IBA on the formation adventitious roots in hypocotyl mung bean.plant Growth Regul., 14:15-19.

[31] Raghavendra, T. and P. Sudhakar (2014). Pattern of plant regeneration from shoot tip explants of pigeonpea (Cajanus cajan L. milllsp) var lrg-41. Int J. App. Biol. Pharm. Technol., 1(5):261-266.

[32] Rai, M. K.; P. Asthana; V. S. Jaiswal and U. Jaiswal (2010). Biotechnological advances in guava (Psidium guajava L.): Recent developments and prospects for future research. Trees, 24, 1-12.

[33] Roussos, P.A. and C.A. Pontikis (2001). Oxidative browning in 'Koroneiki' olive explants as influenced by oxidative enzymatic activities and endogenous phenolic compounds. J. Hort. Sci. Biotechnol.76: 441-446.

[34] Zosa, M. P. G.; M. Sylvia and V. S. Rosario (2008). Psidium guajava L.: A review of its traditional uses, phytochemistry and pharmacol. J. of Ethnopharmacology (1): 1-27.

[35] Rout, G.R.; B.K. Debata and P. Das (2000). In vitro clonal multiplication of roses. Proceedings of the National Academy of Sciences (India) 60, 311-318.

[36] Ryu, N. H.; K.R. Park.; S. M. Kim; H. M Yun; D. Nam; S. G Lee; H. J. Jang; K. S. Ahn;S. H Kim; B. S. Shim S. H. Choi; A. Mosaddik; S. K. Cho; and K. S. Ahn, (2012). A hexane fraction of guavaleaves (Psidium guajava L.) induces anticancer activity by suppressing AKT/mammalian target of rapamycin/ribosomal p70 S6 kinase in human prostat cancer cells.J.Med. Food. 15: $231-241$.

[37] Saelew, N. and Y.S. Yang (2009). Studies on initial shoot tip culture of Guava (Psidium gujava L.). Horti. NCHU. 34 (3):1-14. 
[38] Sambe, M.A.N.; M. Sagna and M.O. Sy (2010). Seed germination and in vitro regeneration of Parkia biglobosa (Jacq.) Benth. Afr. J Biotechnolgy, 9 (21):3099-3108.

[39] Sanda, K.A.; H.A. Grema; Y. A. Geidam and Y. M. Bukar-Kolo (2011). Pharmacological a spects of Psidium guajava L. An up date. Int. J.

[40] Samson, J.A. (1986). Tropical fruits, $2^{\text {nd }}$ ed., Tropical Agriculture Series, Longman Scientific \& Technical, Longman Inc., New York.

[41] Siddique, I. and M. Anis (2009). Morphogenic response of the alginate encapsulated nodal segment and antioxidative enzymes analysis during acclimatization of Ocimum basilicum L. Journal of Crop Science and Biotechnology, 12: 233-238.

[42] Silveiraa,S. S.; R. Cordeiro-Silvab; J. Degenhardt-Goldbachc and M. Quoirinb (2016). Micropropagation of Calophyllum brasiliense (Cambess.) from nodal segments. Braz. J. Biol., 76, (3) 656-663.

[43] Singh, G. (2005). High density planting in guava - application of canopy rchitecture. ICAR News, 11: 9-10.

[44] Snedecor, G.W., and Cochran, W.G. (1990). Statistical Methods, $8^{\text {th }}$ edn, (Iowa State University Press, Ames, Iowa, USA).

[45] Sutter, E.; G. K. D. E. Shackel and J.C. Diaz (1992). Acclimatization of tissue cultured plants. Acta Hort., 314:115-118.

[46] Tripathi, L.; A.K. Singh; S. Singh; R. Singh; S. Chaudhary; I. Sanyal and D.V Amla. (2013). Optimization of regeneration and Agrobacterium-mediated transformation of immature cotyledons of chickpea (Cicer arietinum L.) Plant Cell Tissue Organ Culture, 113(3):513-527.

[47] Usman, M.; M. Butt and B. Fatima (2012). Enhanced in vitro multiple shoot induction in elite Pakistani guava cultivars for efficient clonal plant multiplication. African Journal of Biotechnology, vol. 11 (44), 10182-19187.

[48] Vanstaden, J.; E. Zazimalova and E.F. George (2008). Plant growth regulators

[49] II: Cytokinins, their analogues and antagonist. In: George, E.F.; M. Hall and G.J.De Kleck, eds. Plant Propagation by Tissue Culture., vol. 1. The Background. Springer, The Netherlands, 205-226.

[50] Verheij, E.W.M and R.E. Coronel (Eds.), 1991. Plant resources of South-East Zhou, H. M.; X. Li; Zhou; X. Fany and A. Duo (2010). Plant regeneration from in vitro leaves of the peach rootstock Nemagaured (Prunus persica X P. davidiana) .Plant Cell Tissue Organ culture. 101: 79-87.

Sabah A. Hassanen. "Micropropagation of guava (Psidium guajava L.)." IOSR Journal of Agriculture and Veterinary Science (IOSR-JAVS) 10.7 (2017): 28-35. 